\title{
Association between adefovir dipivoxil treatment and the risk of renal insufficiency in patients with chronic hepatitis B: A meta-analysis
}

\author{
QIAO YANG ${ }^{1}, \mathrm{YU} \mathrm{SHI}^{2}, \mathrm{YING}^{\mathrm{YANG}^{2}}$, GUOHUA LOU ${ }^{2}$ and FANGFANG LV ${ }^{1}$ \\ ${ }^{1}$ Department of Infectious Diseases, Sir Run Run Shaw Hospital; \\ ${ }^{2}$ State Key Laboratory for Diagnosis and Treatment of Infectious Diseases, The First Affiliated Hospital, \\ School of Medicine, Zhejiang University, Hangzhou, Zhejiang 310016, P.R. China
}

Received October 24, 2014; Accepted December 23, 2014

DOI: $10.3892 /$ br.2015.415

\begin{abstract}
Adefovir dipivoxil (ADV) is an effective antiviral drug against hepatitis B virus. The renal tolerance of ADV at the currently approved dose of $10 \mathrm{mg}$ daily for the treatment of chronic hepatitis B (CHB) remains controversial. The present meta-analysis was therefore performed to evaluate the renal safety of ADV treatment in patients with $\mathrm{CHB}$. Two independent investigators searched MEDLINE, Embase and China National Knowledge Infrastructure databases for eligible studies published in English or Chinese until June 1, 2014. The Peto odds ratios (Peto ORs) or the rates of each study were analyzed. Seven randomized controlled trials (RCTs), four cohort studies and six single-arm studies were identified. ADV treatment was not associated with a higher incidence of nephrotoxicity in RCTs [Peto OR, 1.781; $95 \%$ confidence interval $(\mathrm{CI}), 0.637-4.979 ; \mathrm{P}=0.271]$ but appeared to increase nephrotoxicity significantly in cohort studies (Peto OR, 2.682; 95\% CI, 1.470-4.894; P=0.001); the significant increase was further observed in $\mathrm{CHB}$ patients receiving long-term ADV treatment in cohort studies (Peto OR, 2.275; 95\% CI, 1.127-4.593; $\mathrm{P}=0.022)$. The analysis based on single-arm studies showed that the rate of renal dysfunction in the ADV-treated patients was 10.6\% (95\% CI, 0.059-0.185); the subgroup analysis with the standard of createnine levels showed a lower rate $(6.9 \%, 95 \%$ CI, $0.013-0.298)$ than those in the overall studies. In conclusion, although current evidence indicated a positive link between treatment with ADV in CHB
\end{abstract}

Correspondence to: Professor Fangfang Lv, Department of Infectious Diseases, Sir Run Run Shaw Hospital, School of Medicine, Zhejiang University, 3 Qingchun East Road, Hangzhou, Zhejiang 310016, P.R China

E-mail: 13666681531@163.com

Key words: adefovir dipivoxil, renal insufficiency, chronic hepatitis B patients and an increased risk of renal dysfunction, optimally designed studies are required for definitive conclusions.

\section{Introduction}

Adefovir dipivoxil (ADV) is an orally-administered nucleotide analog reverse transcriptase inhibitor, which was initially used to treat human immunodeficiency virus (HIV) infection. However, nephrotoxicity has been proved as an unacceptable side-effect of high-dose (60-120 mg daily) ADV treatment, which may limit its therapeutic usefulness (1). ADV is currently a prescription medication used to treat chronic infection with hepatitis B virus (HBV) and a rescue-therapy for lamivudine-resistant HBV infection (2). The recommended daily dose (10 $\mathrm{mg}$ for adults with normal renal function) of ADV is well-tolerated and exhibits a similar adverse-effect profile to that of the placebo in previous clinical trials with a median follow-up period $(3,4)$. However, the integration of HBV DNA into the human hepatocyte DNA following infection indicates the requirement of long-term therapy for an indefinite period of time. Therefore, the side-effects, particularly nephrotoxicity, are the major concern of long-term treatment of ADV.

In a previous retrospective case-control study, Tamori et al (5) reported that exposure to ADV is associated with an increased incidence of treatment-related renal dysfunction, particularly in patients with cirrhosis and those who receive long-term antiviral therapy. In an open-label trial of long-term ADV therapy for hepatitis B e-antigen-positive chronic hepatitis $\mathrm{B}(\mathrm{CHB})$ patients, reversible creatinine elevations occurred in $8 \%$ patients and notable renal dysfunction was uncommon (6). To improve the understanding of the impact of ADV on renal function in patients with $\mathrm{CHB}$, a systematic review and a meta-analysis were conducted to evaluate whether ADV therapy leads to a high risk of renal dysfunction.

\section{Materials and methods}

Data sources and literature searches. Two independent investigators (Q.Y. and Y.S.) searched MEDLINE, Embase and 
China National Knowledge Infrastructure with the medical subject heading terms and free keywords: 'Adefovir dipivoxil', 'adverse effect', 'side effect', 'HBV infection', 'nephrotoxicity', 'renal dysfunction' and 'renal impairment,' to identify relevant human studies until June 1, 2014. To maximize the sample size and for more comprehensive searching, the reference lists of the included and retrieved studies identified in the initial search were screened further manually. The studies that were not published as full reports, such as letters to editors, meeting summaries and theses, were excluded. The language of the reviewed studies was limited to English and Chinese. Any disagreements between the investigators were resolved by a consensus between them.

Criteria for study selection. The criteria for the study selection were defined prior to the initiation of the literature search. Studies were considered eligible if they: i) Included CHB patients with ADV as mono-therapy or combination therapy in naïve or rescue treatment of $\mathrm{HBV}$ infection; and ii) provided data on the safety of ADV in renal function. The exclusion criteria were as follows: i) Studies on patients co-infected with HIV, hepatitis C or hepatitis D virus; ii) studies on patients with uncompensated CHB; iii) studies on organ transplant recipients; and iv) studies on patients with pre-existing renal diseases or prescribed with potential nephrotoxic medications. When several studies pertaining to one study were identified, the primary publication was selected.

Data extraction and quality assessment. The following information was obtained from each study: i) First author; ii) year of publication; iii) location of study; iv) numbers of patients enrolled and analyzed; v) therapy regimen; vi) definition of renal dysfunction; and vii) data estimating the risk of renal dysfunction. In order to avoid bias during the data abstraction process, two investigators independently extracted relevant data from the trials and subsequently resolved the discrepancies by discussion with the assistance of an arbiter when necessary. The quality assessment of all the studies was based on the schema of evidence assignment developed by the Centre for Evidence-based Medicine in Oxford, UK (7). In addition, the scoring of the included randomized controlled trials (RCTs) studies was based on the Jadad scoring method (8).

Statistical analysis. The quantitative meta-analysis was performed separately among RCTs, cohort studies and single-arm studies using STATA version 10.0 (StataCorp, College Station, TX, USA) and Meta-Analyst Beta 3.13 (Tufts Evidence-based Practice Center, Boston, MA, USA; under contract with the US Agency for Healthcare Research and Quality). Since ADV-associated nephrotoxicity is a relatively rare event, the Peto odds ratio (Peto OR) was used to assess the meta-analysis of the RCTs and cohort studies. The rates were calculated to assess the proportions of nephrotoxic events in single-arm studies. Heterogeneity was estimated by Cochrane's Q-test and $\mathrm{I}^{2}$ measurement $\left(\mathrm{I}^{2}\right.$ are defined as the proportion of total variations across studies, which are due to heterogeneity rather than chance). $\mathrm{P} \leq 0.10$ and $\mathrm{I}^{2} \geq 50 \%$ indicate significant heterogeneity. Based on the statistical significance of the heterogeneity test, a fixed-effects or a random-effects

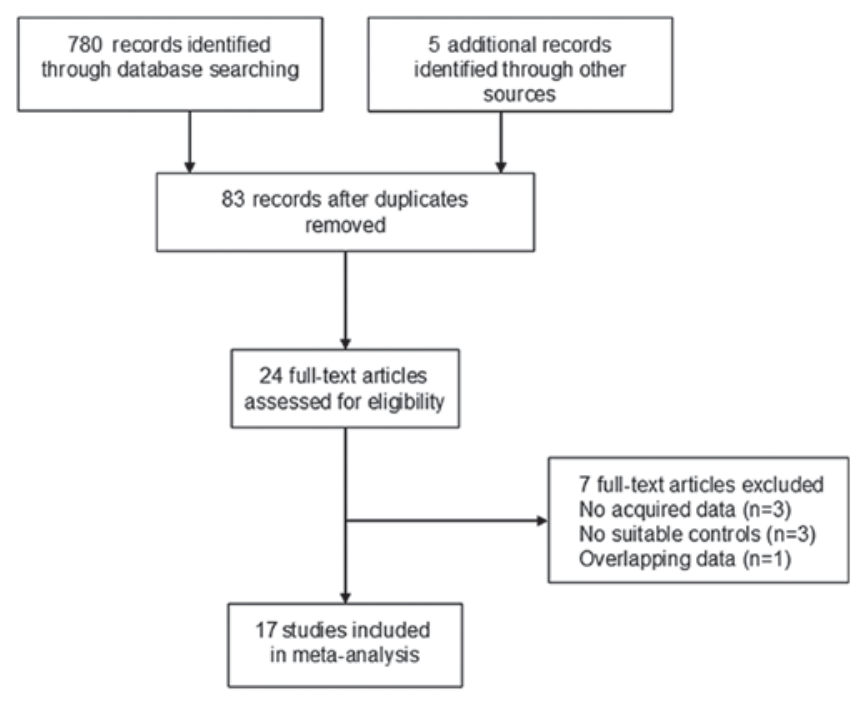

Figure 1. Flow chart of the study selection.

model was applied in the meta-analysis. The Egger's test was used to assess the possible risk of the publication bias and $\mathrm{P} \leq 0.10$ indicates the presence of a publication bias.

\section{Results}

Characteristics of the enrolled studies and quality. A total of 785 potentially eligible studies were initially screened independently. Subsequent to reviewing the titles and abstracts, 24 studies reporting the safety of ADV in patients with $\mathrm{CHB}$ were considered eligible for inclusion in the meta-analysis. Of the 24 studies, seven were excluded as they did not provide acquired data for calculating the incidence of nephrotoxicity, three were excluded as they did not set suitable control groups, and one was excluded as the same authors published overlapping data on the same patients and only the larger study with the longer follow-up period was considered. Subsequently, 17 studies met all the inclusion criteria following a systematic review (Fig. 1) (3,9-24). Of the 17 studies, seven were RCTs (3,9-14), four were cohort studies (15-18) and the remaining six were single-arm studies $(5,19-23)$. The baseline characteristics and quality assessment of the publications are shown in Tables I-III. Thirty-five percent of the studies were performed in multiple countries $(3,9-12,15), 41.2 \%$ were in Asia $(5,16-18,21-23)$ and $23.5 \%$ were in Europe $(13,14,19,20)$. Of the studies included, the follow-up period of six studies lasted for $\sim 1$ year $(3,9-12,18), 10$ for $2-5$ years $(5,14-17,19-23)$ and one for $<7.5$ years (13). All the studies included were of high quality.

Meta-analysis of RCTs. Seven RCTs involving 1,613 subjects were conducted to assess the summary risk estimates of nephrotoxicity during ADV treatment in CHB patients (3,9-14). Pooled data from these RCTs showed no differences between the control therapy and ADV treatment [Peto OR, 1.781; 95\% confidence interval (CI), 0.637-4.979; $\mathrm{Z}=1.10 ; \mathrm{P}=0.271$; Fig. 2]. The overall test for heterogeneity showed that $I^{2}=10.1 \%$ $\left(\chi^{2}=3.34, \mathrm{df}=3, \mathrm{P}=0.343\right)$, indicating there was no evidence of statistical heterogeneity between the studies. Subsequently, a sensitivity analysis was performed by excluding the studies 
Table I. Characteristics of the randomized controlled trials included in the present meta-analysis.

\begin{tabular}{|c|c|c|c|c|c|c|c|c|c|c|}
\hline $\begin{array}{l}\text { First author, } \\
\text { year (PMID) }\end{array}$ & Location & $\begin{array}{c}\text { Enrollment } \\
\mathrm{n}\end{array}$ & $\begin{array}{l}\text { Analysis, } \\
\mathrm{n}\end{array}$ & $\begin{array}{l}\text { Age- } \\
\text { matched }\end{array}$ & $\begin{array}{l}\text { Gender- } \\
\text { matched }\end{array}$ & $\begin{array}{l}\text { Therapy } \\
\text { regimen }\end{array}$ & $\begin{array}{l}\text { Follow-up, } \\
\text { weeks }\end{array}$ & $\begin{array}{l}\text { Definition of } \\
\text { renal dysfunction }\end{array}$ & $\begin{array}{l}\text { Quality } \\
\text { scorces }\end{array}$ & (Refs.) \\
\hline $\begin{array}{l}\text { Marcellin } 2003 \\
(12606735)\end{array}$ & Multicenter & 342 & 338 & + & + & $\begin{array}{l}\text { ADV vs. } \\
\text { placebo }\end{array}$ & 48 & $\begin{array}{l}\geq 0.5 \mathrm{mg} / \mathrm{dl} \\
\text { increase from } \\
\text { baseline in } \\
\text { serum creatinine }\end{array}$ & 8 & (3) \\
\hline $\begin{array}{l}\text { Perrillo } 2004 \\
(14699490)\end{array}$ & Multicenter & 92 & 88 & + & + & $\begin{array}{c}\text { ADV+LAM } \\
\text { vs. placebo } \\
+ \text { LAM }\end{array}$ & 52 & $\begin{array}{l}\geq 0.5 \mathrm{mg} / \mathrm{dl} \\
\text { increase from } \\
\text { baseline in } \\
\text { serum creatinine }\end{array}$ & 8 & (9) \\
\hline $\begin{array}{l}\text { Izzedine } 2004 \\
(15327411)\end{array}$ & Multicenter & 338 & 331 & + & + & $\begin{array}{l}\text { ADV vs. } \\
\text { placebo }\end{array}$ & 48 & $\begin{array}{l}\geq 0.5 \mathrm{mg} / \mathrm{dl} \\
\text { increase from } \\
\text { baseline in } \\
\text { serum creatinine }\end{array}$ & 9 & (10) \\
\hline $\begin{array}{l}\operatorname{Lim} 2007 \\
(17983369)\end{array}$ & Multicenter & 695 & 501 & + & + & $\begin{array}{l}\text { ADV vs. } \\
\text { placebo }\end{array}$ & 48 & $\begin{array}{l}\text { Creatinine } \\
\text { increase }\end{array}$ & 7 & (11) \\
\hline $\begin{array}{l}\text { Jonas } 2008 \\
(18433023)\end{array}$ & Multicenter & 293 & 173 & + & + & $\begin{array}{l}\text { ADV vs. } \\
\text { placebo }\end{array}$ & 48 & $\begin{array}{l}\text { Creatinine } \\
\text { increase }\end{array}$ & 6 & (12) \\
\hline $\begin{array}{l}\text { Manolakopoulos } \\
2011 \text { (22093327) }\end{array}$ & Greece & 90 & 90 & + & + & $\begin{array}{l}\text { ADV+LAM } \\
\text { vs. placebo }\end{array}$ & 360 & $\begin{array}{l}>30 \% \\
\text { eCCR decrease }\end{array}$ & 8 & (13) \\
\hline $\begin{array}{l}\text { Mauss } 2011 \\
(21703180)\end{array}$ & Caucasia & 92 & 92 & + & + & $\begin{array}{l}\text { ADV vs. } \\
\text { placebo }\end{array}$ & 96 & $\begin{array}{l}>20 \mathrm{ml} / \mathrm{min} \\
\text { decrease of eGFR } \\
\text { (calculated by } \\
\text { CKD-EPI formula) } \\
\text { from baseline }\end{array}$ & 8 & (14) \\
\hline
\end{tabular}

PMID, PubMed ID; ADV, adefovir dipivoxil; LAM, lamivudine; eCCR, estimated creatinine clearance; eGFR, estimated glomerular filtration rate; CKD-EPI, Chronic Kidney Disease Epidemiology Collaboration.

Table II. Characteristics of the cohort studies included in the present meta-analysis.

\begin{tabular}{|c|c|c|c|c|c|c|c|c|c|c|}
\hline $\begin{array}{l}\text { First author, } \\
\text { year (PMID) }\end{array}$ & Location & $\begin{array}{l}\text { Enrollment, } \\
\mathrm{n}\end{array}$ & $\begin{array}{l}\text { Analysis, } \\
\mathrm{n}\end{array}$ & $\begin{array}{l}\text { Age- } \\
\text { matched }\end{array}$ & $\begin{array}{l}\text { Gender- } \\
\text { matched }\end{array}$ & $\begin{array}{l}\text { Therapy } \\
\text { regimen }\end{array}$ & $\begin{array}{l}\text { Follow-up, } \\
\text { weeks }\end{array}$ & $\begin{array}{l}\text { Definition of } \\
\text { renal dysfunction }\end{array}$ & $\begin{array}{c}\text { Quality } \\
\text { stratification }\end{array}$ & (Refs.) \\
\hline $\begin{array}{l}\text { На } 2009 \\
(19517525)\end{array}$ & Multicentre & 290 & 290 & + & + & $\begin{array}{l}\text { ADV vs. } \\
\text { ETV }\end{array}$ & 120 & $\mathrm{eGFR} \leq 50 \mathrm{ml} / \mathrm{min}$ & High & (15) \\
\hline $\begin{array}{l}\text { Gu } 2010 \\
\text { (In Chinese) }\end{array}$ & China & 585 & 479 & + & + & $\begin{array}{l}\text { ADV vs. } \\
\text { placebo }\end{array}$ & 192 & $\begin{array}{l}\text { Serum creatinine } \\
>124 \mu \mathrm{mol} / 1\end{array}$ & Low & (16) \\
\hline $\begin{array}{l}\text { Yu } 2011 \\
(21492508)\end{array}$ & China & 120 & 99 & + & + & $\begin{array}{c}\text { ADV+ } \\
\text { LAM } \\
\text { vs. ETV }\end{array}$ & 96 & $\begin{array}{l}\geq 0.5 \mathrm{mg} / \mathrm{dl} \\
\text { increase from } \\
\text { baseline in } \\
\text { serum creatinine }\end{array}$ & High & (17) \\
\hline $\begin{array}{l}\text { Li } 2012 \\
(22699063)\end{array}$ & China & 101 & 101 & + & + & $\begin{array}{l}\text { ADV vs. } \\
\text { LDT }\end{array}$ & 52 & $\begin{array}{l}60<\mathrm{eGFR}< \\
90 \mathrm{ml} / \mathrm{min} / 1.73 \mathrm{~m}^{2}\end{array}$ & Medium & (18) \\
\hline
\end{tabular}

PMID, PubMed ID; ADV, adefovir dipivoxil; ETV, entecavir; eGFR, estimated glomerular filtration rate; LAM, lamivudine; LDT, telbivudine.

one by one. The exclusion of an individual study did not alter the overall result. No statistically significant publication bias was found by Egger's test $(\mathrm{P}=0.919)$.

To determine whether the length of follow-up period may alter the impact of ADV on patient renal function, a subgroup analysis of the studies was further performed with a follow-up period $\geq 2$ years $(13,14)$. The subgroup analysis revealed that the patients treated with ADV did not show a higher risk of nephrotoxicity compared to those treated with control therapies (Peto OR, 1.266; 95\% CI, 0.400-4.012; $\mathrm{Z}=0.40, \mathrm{P}=0.688$ ). 
Table III. Characteristics of the single-arm studies included in the present meta-analysis.

\begin{tabular}{|c|c|c|c|c|c|c|c|c|c|c|}
\hline $\begin{array}{l}\text { First author, } \\
\text { year (PMID) }\end{array}$ & Location & $\begin{array}{c}\text { Experimental } \\
\text { design }\end{array}$ & $\begin{array}{l}\text { Enrollment, } \\
\mathrm{n}\end{array}$ & $\begin{array}{c}\text { Analysis, } \\
\mathrm{n}\end{array}$ & $\begin{array}{l}\text { Age, } \\
\text { median }\end{array}$ & $\begin{array}{l}\text { Therapy } \\
\text { regimen }\end{array}$ & $\begin{array}{l}\text { Follow-up, } \\
\text { weeks }\end{array}$ & $\begin{array}{l}\text { Definition of } \\
\text { renal dysfunction }\end{array}$ & $\begin{array}{c}\text { Quality } \\
\text { stratification }\end{array}$ & (Refs.) \\
\hline $\begin{array}{l}\text { Lampertico } \\
2007 \\
(17983801)\end{array}$ & Belgium & Prosp & 282 & 145 & 56 & $\begin{array}{l}\text { ADV+ } \\
\text { LAM }\end{array}$ & 182 & $\begin{array}{l}\geq 0.5 \mathrm{mg} / \mathrm{dl} \\
\text { increase from } \\
\text { baseline in } \\
\text { serum creatinine }\end{array}$ & High & (19) \\
\hline $\begin{array}{l}\text { Vassiliadis } \\
2010 \\
(19780875)\end{array}$ & Greece & Prosp & 60 & 60 & 56 & $\begin{array}{c}\text { ADV+ } \\
\text { LAM } \\
\text { and ADV }\end{array}$ & 212 & $\begin{array}{l}\text { Increase in } \\
\text { creatinine levels }\end{array}$ & High & (20) \\
\hline $\begin{array}{l}\text { Tamori } \\
2010 \\
(19674281)\end{array}$ & Japan & Prosp & 37 & 37 & 55 & $\begin{array}{c}\mathrm{ADV}+ \\
\mathrm{LAM}\end{array}$ & 144 & $\begin{array}{l}\text { Serum creatinine } \\
\text { levels increased } \\
\text { to }>130 \% \text { of the } \\
\text { baseline }\end{array}$ & High & (5) \\
\hline $\begin{array}{l}\text { Kim } \\
2012 \\
(21777281)\end{array}$ & Korea & Retr & 1057 & 687 & 49 & ADV & 108 & $\begin{array}{l}\text { eGFR (measured } \\
\text { by Cockcroft-Gault } \\
\text { formula) decreased } \\
>20 \% \text { of the baseline }\end{array}$ & Medium & (21) \\
\hline $\begin{array}{l}\text { Zhu } 2012 \\
(23547463)\end{array}$ & China & Retr & 31 & 31 & 72 & ADV & 144 & $\begin{array}{l}\text { Serum creatinine } \\
\text { levels increased } \\
\text { to }>130 \% \text { of the } \\
\text { baseline }\end{array}$ & Medium & (22) \\
\hline $\begin{array}{l}\text { Tanaka } 2014 \\
(23525978)\end{array}$ & Japan & Retr & 292 & 292 & 47 & $\begin{array}{l}\mathrm{ADV}+ \\
\mathrm{LAM}\end{array}$ & 256 & $\begin{array}{l}\text { eGFR } \\
<50 \mathrm{ml} / \mathrm{min} / 1.73 \mathrm{~m}^{2}\end{array}$ & High & (23) \\
\hline
\end{tabular}

PMID, PubMed ID; Prosp, prospective; ADV, adefovir dipivoxil; LAM, lamivudine; Retr, retrospective; eGFR, estimated glomerular filtration rate.

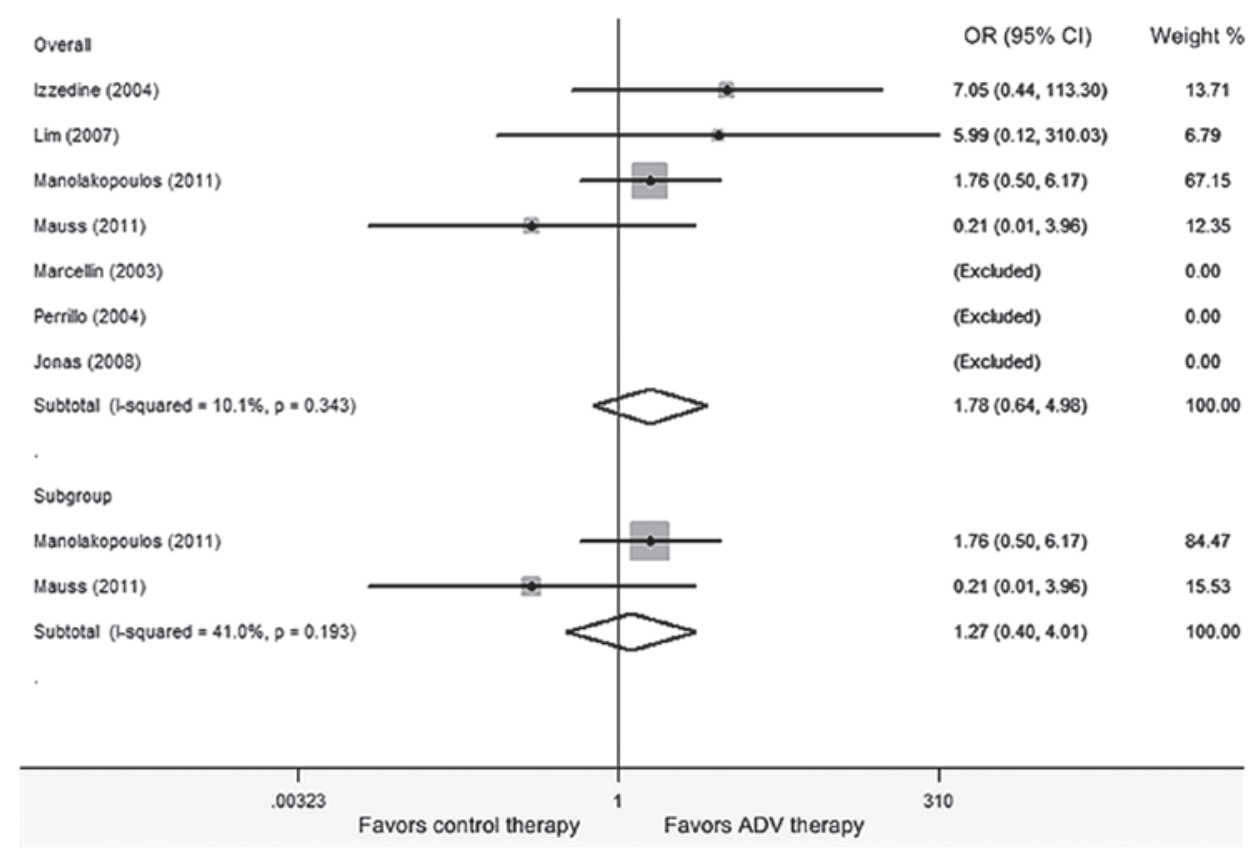

Figure 2. Meta-analysis of the ORs of the nephrotoxicity risk between adefovir and control therapy using the Peto model for randomized controlled trials. The areas of the squares are proportional to the weights used for combining the data; diamonds represent overall risk estimates; horizontal lines represent $95 \%$ CI. OR, odds ratio; CI, confidence interval; ADV, adefovir dipivoxil.

The overall test for heterogeneity showed that $\mathrm{I}^{2}=41.0 \%$ $\left(\chi^{2}=1.70, \mathrm{df}=1, \mathrm{P}=0.193\right)$, indicating no significant heterogeneity between the studies.
Meta-analysis of cohort studies. Four cohort studies involving 969 subjects were included in the analysis (Table II) (15-18). The results showed that ADV was associated with a significant 


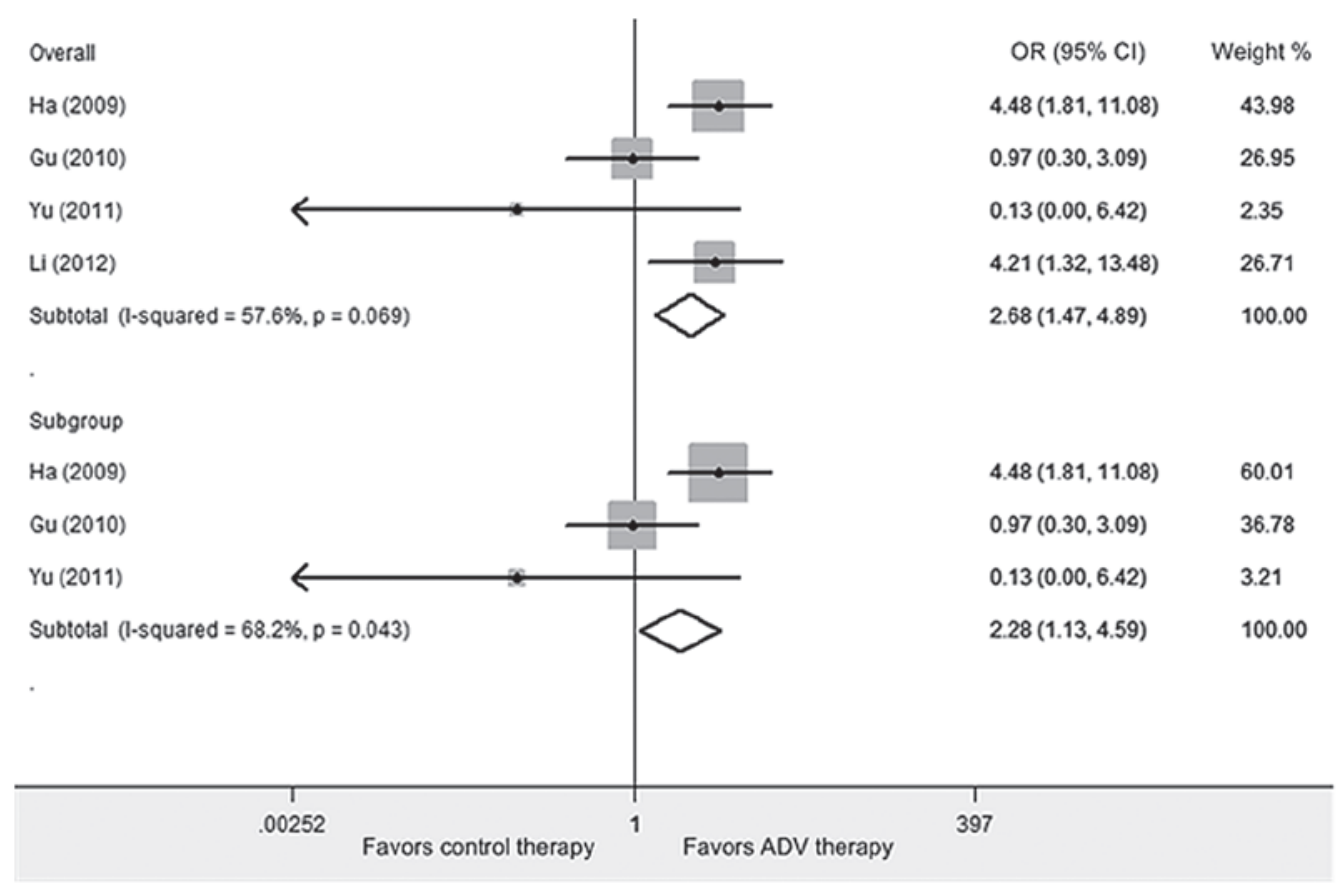

Figure 3. Meta-analysis of the ORs of the nephrotoxicity risk between adefovir and control therapy for cohort studies using the Peto model. The areas of the squares are proportional to the weights used for combining the data; diamonds represent overall risk estimates; horizontal lines represent $95 \%$ CI. OR, odds ratio; $\mathrm{CI}$, confidence interval; $\mathrm{ADV}$, adefovir dipivoxil.

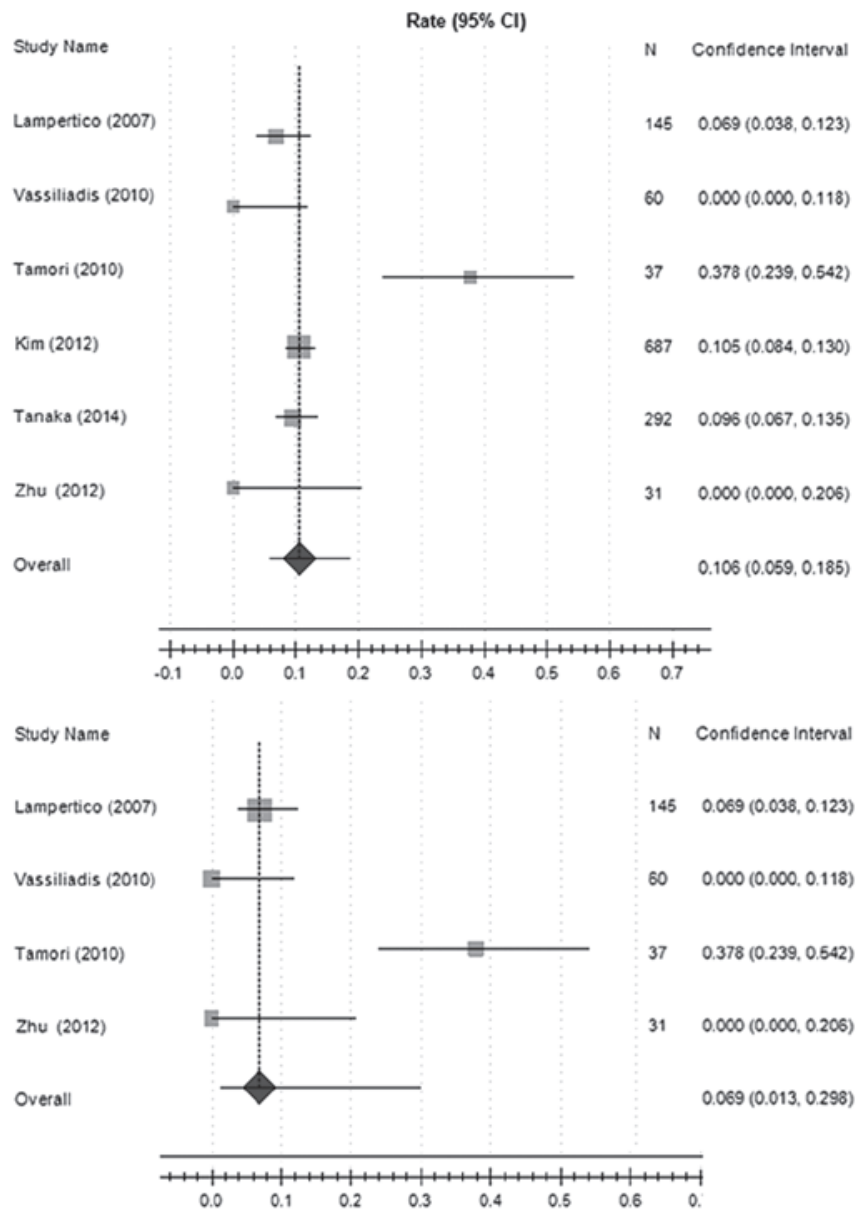

Figure 4. Meta-analysis of the rates of nephrotoxicity with adefovir therapy for single-arm studies using the random (DerSimonian-Laird) model. The areas of the squares are proportional to the weights used for combining the data; diamonds represent overall risk estimates; horizontal lines represent $95 \%$ CI. CI, confidence interval. excess risk of nephrotoxicity in CHB patients (Peto OR, 2.682; 95\% CI, 1.470-4.894; $\mathrm{Z}=3.22$; $\mathrm{P}=0.001$; Fig. 3). The median level of between-study heterogeneity was found $\left(\chi^{2}=7.08, \mathrm{df}=3\right.$, $\mathrm{P}=0.069, \mathrm{I}^{2}=57.6 \%$ ). Evaluation of publication bias showed that the Egger's test was not significant $(\mathrm{P}=0.313)$. From three cohort studies of $\geq 2$ years follow-up period, data was obtained for analysis (15-17). The present subgroup analysis revealed that there was a significantly higher risk of nephrotoxicity in patients with ADV treatment compared to those with control therapies (Peto OR, 2.275; 95\% CI, 1.127-4.593; $Z=2.29 ; P=0.022)$. Statistical heterogeneity between the studies was found $\left(\chi^{2}=6.29, \mathrm{df}=2\right.$, $\left.\mathrm{P}=0.043, \mathrm{I}^{2}=68.2 \%\right)$. Egger's test indicated there is no statistically significant bias of publication $(\mathrm{P}=0.457)$.

Meta-analysis of single-arm studies. The rates of renal dysfunction in the overall ADV-treated subjects were pooled from six single-arm studies $(5,19-23)$. The total rate was $10.6 \%$ (95\% CI, 0.059-0.185). The medium between-study heterogeneity was observed $\left(\tau^{2}=0.292, \mathrm{df}=0.833, \mathrm{P}=0.000, \mathrm{I}^{2}=45.6 \%\right.$; Fig. 4). No significant publication bias was found by Egger's test $(\mathrm{P}=0.494)$. Evidence shows that the method used to assess renal dysfunction may affect the estimated results. Therefore, a subgroup analysis was performed by the detection method of renal dysfunction [serum creatinine levels or estimated glomerular filtration rate (eGFR)]. A slight to moderate decrease in the pooled rates $(6.9 \%$; $95 \%$ CI, 0.013-0.298) was observed when the studies were restricted to those using serum creatinine levels as the indicator of renal function $(5,19,20,22)$.

\section{Discussion}

The nucleotide analogue ADV has been approved as an efficient treatment for $\mathrm{CHB}$ and as an add-on rescue treatment 
for CHB patients with lamivudine resistance in $2002(24,25)$. Although the potent efficacies of ADV in virological, biochemical and histological improvements have been recognized, the possible adverse event (such as nephrotoxicity) remains a concern, particularly in patients requiring prolonged treatment or those with pre-existing renal diseases $(26,27)$. Certain studies specifically focus on the renal complications during ADV therapy, indicating the requirement for a systematic meta-analysis of nephrotoxicity associated with ADV therapy in chronic HBV infection.

The present study examined the association between ADV therapy and the risk of nephrotoxicity in $\mathrm{CHB}$ patients. The pooled Peto OR $(1.781 ; 95 \% \mathrm{CI}, 0.637-4.979 ; \mathrm{P}=0.271)$ of seven RCTs involving 1,613 CHB patients demonstrated that the incidence of ADV-related nephrotoxicity is similar to that of control therapies (Fig. 2). The result was confirmed by a longer follow-up period following the removal of the studies with shorter periods. These RCTs data indicate that daily treatment with ADV is well-tolerated and ADV treatment did not appear to increase the risk of developing renal dysfunction in CHB patients. However, the dose of ADV should be adjusted according to patient eGFR during the follow-up periods; these RCTs did not adjust the does according to the eGFR, which may underestimate the rate of renal dysfunction.

In contrast to the results of the RCTs, the pooled Peto OR (2.682; 95\% CI, 1.470-4.894; $\mathrm{P}=0.001)$ of four cohort studies showed a $\sim 1.7$-fold increased risk of nephrotoxicity in $\mathrm{CHB}$ patients with ADV treatment. This association remained significant following the exclusion of a study with a short follow-up period (Peto OR, 2.275; 95\% CI, 1.127-4.593; $\mathrm{P}=0.022)$. In addition, a median level of heterogeneity $\left(\mathrm{P}=0.069, \mathrm{I}^{2}=57.6 \%\right)$ was observed during the overall analysis, and substantial between-study heterogeneities $(\mathrm{P}=0.043$, $\mathrm{I}^{2}=68.2 \%$ ) were found when performing the subgroup analysis, which may be a limitation of the validity of the results, even though a Peto model was applied that takes possible heterogeneity into consideration. The result also indicated that the follow-up period partially explained the heterogeneity among the studies included.

The present study is of note as different results were found in the risk of nephrotoxicity between the RCTs and cohort studies. The discrepancy of the above results may be due to the different aims of the original studies and the different applicable scopes of the studies. RCT is recognized as the optimal design scheme for evaluating the effectiveness of therapeutic agents $(28,29)$. However, due to its small sample size and the short observational period, the meta-analysis based on the results of RCTs tends to lack adequate safety data and underestimates the adverse events. The risk of a type II error (false negative conclusion) is considerable. Therefore, RCT is not considered suitable to study certain rare adverse events and cautious interpretation of RCT results in the meta-analysis should be required. By contrast, the benefits of cohort studies with large sample size and longer observational period have been noted in evaluating rare adverse events during recent years (30). In the present meta-analysis of the cohort studies, a higher excess risk of nephrotoxicity was observed in individuals treated with ADV compared to those not treated, and the reliability of the primary results was further validated by a subgroup analysis with long-term treatment. However, as the available studies were limited, the subgroup analysis according to the treatment regimens and the definition of renal dysfunction was not performed. Due to the same reason, whether or not study location and gender of patients affect the risk of renal dysfunction could not be explored. The renal safeness of therapy with ADV in long-term use is not enough to be evaluated. To gain a reliable analysis of the occurrence of renal dysfunction during ADV treatment, additional large, long-term, controlled cohort studies addressing these issues are warranted.

Furthermore, a meta-analysis from seven single-arm trials was performed and the pooled analysis demonstrated that the rate of renal dysfunction in the overall ADV-treated patients was $10.6 \%$ (95\% CI, 0.059-0.185). According to Fig. 4, the result of the Tamori et al (5) study is different from the others. The discrepancy may be due to the objects of the above study included patients with cirrhosis, which may overestimate the renal impairment. Analysis of subgroups provides verification that the use of serum creatinine to assess renal dysfunction appears to yield a lower rate of renal dysfunction (rate is $6.9 \%$; 95\% CI, 0.013-0.298), indicating that the standard used to estimate renal function may influence the final results. Certain well-established formulae, such as Cockcroft-Gault and modification of diet in renal disease, used to calculate the eGFR or creatinine clearance are preferentially validated for patients with pre-existing renal impairment $(31,32)$; others were introduced to calculate the eGFR in patients with normal or slightly renal disturbances $(33,34)$. Recently, hypophosphatemia or Fanconi anemia reportedly develops during ADV therapy reflecting renal tubular damage. Serum creatinine and eGFR are insufficient for evaluating renal insufficiency. However, no standard for the evaluation of renal dysfunction during ADV treatment has been unified, which may explain the inconsistent results among the clinical trials. Therefore, future studies in the form of unified clinical trials are required to gain more validated evidence for this issue.

Certain technical issues are associated with the present meta-analysis. The meta-analysis was not based on individual patient data, which tend to overestimate the adverse effects compared to the published data. Publication bias, which is a threat to the validity of the results, did not exist in the present meta-analysis. A limitation of the meta-analysis is the heterogeneity among trials, even though a random-effects model that takes possible heterogeneity into consideration was applied. Another drawback of the meta-analysis is the regional limitation of the cohort studies. The majority of the cohort studies were conducted in the Chinese population and therefore, the conclusion may not be generalized to other populations. Finally, the language of the enrolled studies was limited to English or Chinese, which may exclude certain high-quality studies published in other languages.

In conclusion, the current evidence supports that ADV treatment can pose a risk for renal dysfunction and the nephrotoxic effects progressively increased over exposure time. However, this conclusion requires large, controlled and longitudinal follow-up studies to be strengthened. Further studies should provide details on whether different ADV therapy regimens predispose different risk of renal dysfunction. Other studies should focus on screening for predictors 
of nephrotoxic events in ADV-treated population. The renal safety in particular populations, such as the elderly, children and the liver transplant patients, requires examining as well.

\section{Acknowledgements}

The present study was supported by the National Natural Science Foundation of China (grant no. 81400622) and the 12-5 State S\&T Projects of China (grant no. 2012ZX10002007).

\section{References}

1. Fisher EJ, Chaloner K, Cohn DL, et al: The safety and efficacy of adefovir dipivoxil in patients with advanced HIV disease: a randomized, placebo-controlled trial. AIDS 15: 1695-1700, 2001.

2. Dando T and Plosker G: Adefovir dipivoxil: a review of its use in chronic hepatitis B. Drugs 63: 2215-2234, 2003.

3. Marcellin P, Chang TT, Lim SG, et al: Adefovir dipivoxil for the treatment of hepatitis B e antigen-positive chronic hepatitis B N Engl J Med 348: 808-816, 2003.

4. Hadziyannis SJ, Tassopoulos NC, Heathcote EJ, et al: Adefovir dipivoxil for the treatment of hepatitis $\mathrm{B}$ e antigen-negative chronic hepatitis B. N Engl J Med 348: 800-807, 2003.

5. Tamori A, Enomoto M, Kobayashi S, et al: Add-on combination therapy with adefovir dipivoxil induces renal impairment in patients with lamivudine-refractory hepatitis B virus. J Viral Hepat 17: 123-129, 2010.

6. Marcellin P, Chang TT, Lim SG, et al: Long-term efficacy and safety of adefovir dipivoxil for the treatment of hepatitis $B$ e antigen-positive chronic hepatitis B. Hepatology 48: 750-758, 2008.

7. Pearce-Smith $\mathrm{N}$ and Hunter $\mathrm{J}$ : The introduction of librarian tutors into the Teaching Evidence-Based Medicine week in Oxford, UK. Health Info Libr J 22: 146-149, 2005.

8. Jadad AR, Moore RA, Carroll D, et al: Assessing the quality of reports of randomized clinical trials: is blinding necessary? Control Clin Trials 17: 1-12, 1996.

9. Perrillo R, Hann HW, Mutimer D, et al: Adefovir dipivoxil added to ongoing lamivudine in chronic hepatitis B with YMDD mutant hepatitis B virus. Gastroenterology 126: 81-90, 2004.

10. Izzedine H, Hulot JS, Launay-Vacher V, et al: Renal safety of adefovir dipivoxil in patients with chronic hepatitis B: two double-blind, randomized, placebo-controlled studies. Kidney Int 66: 1153-1158, 2004.

11. Lim SG, Marcellin P, Tassopoulos N, et al: Clinical trial: effects of adefovir dipivoxil therapy in Asian and Caucasian patients with chronic hepatitis B. Aliment Pharmacol Ther 26: 1419-1428, 2007.

12. Jonas MM, Kelly D, Pollack H, et al: Safety, efficacy, and pharmacokinetics of adefovir dipivoxil in children and adolescents (age 2 to $<18$ years) with chronic hepatitis B. Hepatology 47: $1863-1871,2008$.

13. Manolakopoulos S, Striki A, Deutsch M, et al: Long-term adefovir plus lamivudine therapy does not decrease creatinine clearance in HBeAg-negative chronic hepatitis B patients. Liver Int 31: 1525-1532, 2011

14. Mauss S, Berger F, Filmann N, et al: Effect of HBV polymerase inhibitors on renal function in patients with chronic hepatitis B. J Hepatol 55: 1235-1240, 2011.

15. Ha NB, Ha NB, Garcia RT, et al: Renal dysfunction in chronic hepatitis B patients treated with adefovir dipivoxil. Hepatology 50: 727-734, 2009.
16. Gu SW, Zhao B, Sun YY, et al: The effect of different doses of adefovir dipivoxil on renal function. Chin Hepatol 15: 247-250, 2010 (In Chinese).

17. Yu JH, Shi JP, Wu J, et al: Efficacy and safety of lamivudine plus adefovir combination therapy and entecavir monotherapy for chronic hepatitis B patients. Zhonghua Gan Zang Bing Za Zhi 19: 88-92, 2011 (In Chinese).

18. Li X, Zhong C, Yang S, et al: Influence of adefovir dipivoxil or telbivudine monotherapy on renal function of patients with chronic hepatitis B. Nan Fang Yi Ke Da Xue Xue Bao 32: 826-829, 2012 (In Chinese).

19. Lampertico P, Viganò M, Manenti E, et al: Low resistance to adefovir combined with lamivudine: a 3-year study of 145 lamivudine-resistant hepatitis B patients. Gastroenterology 133: 1445-1451, 2007.

20. Vassiliadis TG, Giouleme O, Koumerkeridis G, et al: Adefovir plus lamivudine are more effective than adefovir alone in lamivudine-resistant $\mathrm{HBeAg}$ - chronic hepatitis B patients: a 4-year study. J Gastroenterol Hepatol 25: 54-60, 2010.

21. Kim YJ, Cho HC, Sinn DH, et al: Frequency and risk factors of renal impairment during long-term adefovir dipivoxil treatment in chronic hepatitis B patients. J Gastroenterol Hepatol 27: 306-312, 2012

22. Zhu MF, Qian JC, Lu L, et al: Three-year efficacy and side effect of adefovir dipivoxil for the treatment of the old patients with chronic hepatitis B virus infection. Zhonghua Shi Yan He Lin Chuang Bing Du Xue Za Zhi 26: 379-381, 2012 (In Chinese).

23. Tanaka M, Suzuki F, Seko Y, et al: Renal dysfunction and hypophosphatemia during long-term lamivudine plus adefovir dipivoxil therapy in patients with chronic hepatitis B. J Gastroenterol 49: 470-480, 2014

24. Peters MG, Hann Hw Hw, Martin P, et al: Adefovir dipivoxil alone or in combination with lamivudine in patients with lamivudine-resistant chronic hepatitis B. Gastroenterology 126: 91-101, 2004

25. Seto WK, Liu K, Fung J, et al: Outcome of lamivudine-resistant chronic hepatitis B after up to 5 years of combination therapy with adefovir. Antivir Ther 17: 1255-1262, 2012.

26. Schiff ER, Lai CL, Hadziyannis S, et al: Adefovir dipivoxil therapy for lamivudine-resistant hepatitis B in pre- and post-liver transplantation patients. Hepatology 38: 1419-1427, 2003.

27. Schiff E, Lai CL, Hadziyannis S, Neuhaus P, et al: Adefovir dipivoxil for wait-listed and post-liver transplantation patients with lamivudine-resistant hepatitis B: final long-term results. Liver Transpl 13: 349-360, 2007.

28. Byar DP, Simon RM, Friedewald WT, et al: Randomized clinical trials. Perspectives on some recent ideas. N Engl J Med 295: 74-80, 1976.

29. Abel U and Koch A: The role of randomization in clinical studies: myths and beliefs. J Clin Epidemiol 52: 487-497, 1999.

30. Benson K and Hartz AJ: A comparison of observational studies and randomized, controlled trials. N Engl J Med 342: 1878-1886, 2000.

31. Levey AS, Bosch JP, Lewis JB, et al: A more accurate method to estimate glomerular filtration rate from serum creatinine: a new prediction equation. Modification of Diet in Renal Disease Study Group. Ann Intern Med 130: 461-470, 1999.

32. Cockcroft DW and Gault MH: Prediction of creatinine clearance from serum creatinine. Nephron 16: 31-41, 1976.

33. Levey AS, Stevens LA, Schmid CH, et al: A new equation to estimate glomerular filtration rate. Ann Intern Med 150: 604-612, 2009.

34. Lujan PR, Chiurchiu C, Douthat W, et al: CKD-EPI instead of MDRD for candidates to kidney donation. Transplantation 94 . 637-641, 2012. 